\title{
Bladder Irrigation
}

National Cancer Institute

\section{Source}

National Cancer Institute. Bladder Irrigation. NCI Thesaurus. Code C15397.

Instillation of a solution into the bladder to provide cleansing or medication. 